\title{
ANALISIS PENGARUH BUDAYA KAIZEN TERHADAP KINERJA KARYAWAN DENGAN REWARD SEBAGAI VARIABEL MODERASI DALAM RANGKA PENGUATAN DAYA SAING BISNIS
}

\author{
Erix Pamungkas ${ }^{1}$ dan Rosaly Franksiska ${ }^{2}$ \\ Universitas Kristen Satya Wacana \\ Jl. Diponegoro 52-60, Salatiga - Indonesia 50711 \\ Email: 1erixpamungkas20@gmail.com, ${ }^{2}$ rosaly.franksiska@staff.uksw.edu
}

\begin{abstract}
Every company has its own organizational culture, in which the organizational culture will affect the employee performance and also company performance. Kaizen culture originated from Japan is a culture of continuous improvement with low cost and the impact can be felt in the future. If the Kaizen culture combined with reward will also be able to improve the employee performance. The purpose of this research is to analyze the influence of Kaizen culture to employee performance with reward as a moderating variable. This a quantitative exploratory research using Moderated Regression Analysis (MRA). The data collection method is using questionnaire, with sample of 93 respondents of warehouse department of PT SM Karangjati, Semarang. The result of this study indicated that Kaizen culture influence employee performance and reward can moderate or strengthen the impact of Kaizen culture on employee performance.
\end{abstract}

Keywords: Kaizen culture, Employee Performance, Non-Financial Reward, Financial Reward

\begin{abstract}
Abstrak
Setiap perusahaan memiliki budaya organisasi masing-masing, dimana budaya organisasi tersebut akan mempengaruhi kinerja dari karyawannya dan kinerja dari perusahaan. Budaya kaizen merupakan budaya perbaikan berkesinambungan dengan biaya yang rendah dan imbal hasil yang dirasakan di masa mendatang. Budaya kaizen merupakan budaya perbaikan berkesinambungan dengan biaya yang rendah dan imbal hasil yang dirasakan di masa mendatang. Penelitian ini bertujuan untuk menganalisis pengaruh budaya kaizen terhadap kinerja karyawan dengan reward sebagai variabel moderasi. Penelitian ini adalah penelitian kuantitatif eksploratif menggunakan Moderated Regression Analysis (MRA). Metode pengumpulan data menggunakan kuesioner, dengan sampel sebanyak 93 responden pada Bagian Gudang dari PT SM Karangjati, Semarang. Hasil penelitian ini mengindikasikan bahwa budaya Kaizen berpengaruh pada kinerja karyawan dan reward memoderasi atau memperkuat pengaruh tersebut.
\end{abstract}

Kata Kunci: Budaya Kaizen, Kinerja Karyawan, Non-Financial Reward, Financial Reward

\section{PENDAHULUAN}

Dalam pengelolaan sumber daya manusia agar karyawan memiliki semangat dalam bekerja adalah perusahaan harus memberikan reward atau kompensasi. Perusahaan akan memberikan reward kepada karyawannya jika 
karyawan tersebut memberikan kontribusi yang lebih kepada perusahaan. Pentingnya pemberian reward atau kompensasi sebagai salah satu cara perusahaan agar karyawan mempunyai tangung jawab terhadap perusahaan (Fajarrini P. Hakam Danti, 2014). Dengan adanya reward ini diharapkan dapat meningkatkan kinerja karyawan. Kinerja karyawan akan berpengaruh terhadap kinerja suatu organisasi atau perusahaan. Salah satu faktor dalam upaya meningkatan kinerja karyawan yaitu menerapkan budaya perusahaan yang baik dan benar, tetapi peran budaya organisasi tersebut cenderung kurang disadari dan dipamahi oleh banyak pelaku organisasi di Indonesia (Sinaga, 2008). Perusahaan perlu mengenalkan budaya organisasi atau budaya kerja pada karyawan dengan mensosialisasikan agar persepsi karyawan sesuai dengan apa yang diharapkan oleh perusahaan.

Upaya manajemen sumber daya manusia dalam pencapaian tujuan dari perusahaan, maka harus menciptakan budaya kerja yang baik untuk mendukung sumber daya manusia yang ada di perusahaan. Di negara Jepang ada satu budaya organisasi yang sangat berperan penting pada perusahaan-perusahaan di Jepang yaitu budaya kaizen. Menurut Imai (1998) budaya kaizen telah banyak memberikan kontribusi bagi keberhasilan perusahaanperusahaan yang ada di Jepang. Jika budaya kaizen ini di implementasikan di perusahaanperusahaan di Indonesia, maka akan memberikan pengaruh yang luar biasa bagi kemajuan perusahaan di Indonesia. Kaizen merupakan perbaikan berkesinambungan bersifat kecil dan bertahap, proses kaizen ini mampu membawa hasil yang memuaskan dalam jangka panjang (Imai,1998). Artian dari bersifat kecil dan bertahap adalah dengan biaya yang rendah dan jika dilakukan secara bertahap maka akan menuai hasil yang memuaskan.

Budaya kaizen ini juga mengajarkan untuk displin kerja. Sesuatu pekerjaan jika dilakukan dengan disiplin maka akan menghasilkan sesuatu secara teratur dan baik. Dengan adanya budaya kaizen, perusahaan berharap sistem manajemen dapat berkembang dengan lebih baik, terutama pada kinerja karyawan yang menjadi kunci sukses keberhasilan perusahaan. Dalam membudayakan konsep kaizen, perusahaan harus merangsang inovasi dari karyawan dalam artian perusahaan memberikan kewajiban kepada karyawan untuk menulis ide-ide yang ditujukan untuk mempermudah pekerjaan dari karyawan (www.kompas.com). Dengan membudayakan hal tersebut karyawan akan terbiasa berfikir dan menerapkan budaya kaizen ini dalam pekerjaannya di perusahaan. PT SM Tbk merupakan perusahan yang bergerak di bidang industri jamu. Perusahaan ini merupakan perusahaan operasional penghasil jamu terbesar di Indonesia. Melihat hal tersebut tentunya diperlukan kinerja karyawan yang tinggi. Dengan masuknya budaya kaizen yang baru selama tiga tahun ini, diharapkan dapat memberikan peran penting dalam memberi pengaruh pada kinerja karyawan maupun tujuan dalam mengembangkan dan memajukan perusahaan.

Menurut wawancara pendahuluan dengan asisten kepala gudang PT SM Karangjati, Semarang yang dilakukan pada tanggal 2 Juli 2017 didapatkan hasil bahwa adanya budaya kaizen yaitu 5R (Ringkas, Rapi, Resik, Rawat dan Rajin) di PT SM Karangjati, Semarang terutama di bagian gudang. Perusahaan mewajibkan seluruh karyawannya untuk melakukan budaya kaizen tersebut, agar hasilnya kinerja karyawan menjadi lebih baik. Perusahaan juga sudah menerapkan reward khusus untuk budaya kaizen. Tidak hanya itu saja, di bagian gudang sudah mendisiplinkan mengenai budaya kaizen dikarenakan bagian gudang sendiri merupakan awal dari bahan baku masuk dan proses produksi. Bahan baku yang ada di bagian gudang harus bersih dan baik agar proses produksi sampai dengan barang jadi mendapatkan hasil yang memuaskan. Selama tiga tahun ini budaya kaizen sudah dilakukan di PT SM. Yang masih menjadi kendala di perusahaan tersebut yaitu budaya kerja yang lama masih melekat 
di beberapa karyawan SM di bagian gudang sehingga mengakibatkan masih adanya beberapa karyawan yang kinerjanya belum berubah, walaupun ada beberapa yang sudah berubah. Maka peneliti ingin melalukan penelitian di bagian gudang.

Penelitian mengenai kinerja karyawan telah dilakukan beberapa peneliti diantaranya Tarigan (2011), Zamzami (2015), Sari, dkk (2012), Melindasari (2015) dan lain-lain. Pada penelitian Rohman (2016) dan Muliyawati (2015) mengenai pengaruh budaya kaizen terhadap kinerja karyawan, menunjukan hasil terdapat pengaruh positif budaya kaizen terhadap kinerja karyawan. Pada penelitian Hakim, dkk (2016) mengenai pengaruh budaya kaizen terhadap motivasi dan kinerja, hasilnya terdapat pengaruh yang signifikan antara budaya kaizen terhadap motivasi kerja dan variabel budaya kaizen ini memiliki pengaruh yang signifikan terhadap kinerja karyawan. Ini menandakan bahwa budaya kaizen membawa dampak yang baik bagi kinerja karyawan terutama dalam mencapai tujuan dari perusahaan. Dengan terbatasnya penelitian tersebut, maka dalam penelitian ini ingin menguji kembali bagaimana budaya kaizen ini berpengaruh terhadap kinerja karyawan. Peneliti akan menambahkan variabel reward sebagai variabel moderasi karena menurut penelitian Demokrat (2011) menunjukan bahwa kompensasi atau reward ini memiliki pengaruh yang positif dan mampu meningkatkan kinerja karyawan. Yang membedakan penelitian ini dengan penelitian yang lalu adalah untuk penelitian yang lalu kompensasi atau reward sebagai pengaruh, sedangkan dalam penelitian ini reward sebagai variabel penguat antara pengaruh budaya kaizen terhadap kinerja karyawan.

Persoalan penelitian yang menjadi permasalahan dalam penelitian ini adalah apakah budaya kaizen memiliki pengaruh yang signifikan terhadap kinerja karyawan PT SM Tbk. dengan reward sebagai variabel moderasi. Tujuan dari penelitian ini adalah menganalisis pengaruh budaya kaizen terhadap kinerja karyawan dengan reward sebagai variabel moderasi. Manfaat dari penelitian ini untuk memberikan pengetahuan serta penjelasan mengenai pengaruh budaya kaizen terhadap kinerja karyawan di PT SM Tbk. dengan reward apakah variabel reward dapat memperkuat atau memperlemah pengaruh dari budaya kaizen dan kinerja karyawan.

\section{METODE PENELITIAN}

Penelitian ini menggunakan metode kuantitatif. Penelitian ini menggunakan data primer yang diperoleh dari penelitian lapangan (field research). Penelitian ini dilakukan dengan mengambil responden karyawan di bagian gudang di PT SM Karangjati, Semarang. Teknik pengambilan sampel yang digunakan dalam metode penelitian ini adalah convenience sampling. Jumlah populasi karyawan bagian gudang di PT SM Tbk. yang akan diteliti adalah 120 karyawan. Untuk menguji hipotesis yang ada, maka responden yang akan menjadi sampel (sesuai rumus Slovin) adalah sebanyak 93 karyawan.

Metode yang digunakan untuk mengambil data dari responden adalah menggunakan kuisoner (angket). Untuk variabel budaya kaizen menurut Imai (1998) diukur dengan lima dimensi yaitu ringkas, rapi, resik, rawat, dan rajin. Dengan 14 indikator atau ukuran pada variabel budaya kaizen yang merupakan kombinasi dari Imai (1998), Tangguh (2015) dan Ruslianto (2015). Untuk variabel kinerja menurut Wirawan (2009) diukur dengan tiga dimensi yaitu hasil kerja, perilaku kerja dan sifat pribadi, dengan 9 indikator pengukuran yang merupakan kombinasi dari Wirawan (2009), Melindasari (2015) dan Reza (2010). Untuk variabel reward menurut Bangun (2012) ada dua dimensi pengukuran yaitu reward non finansial dan reward finansial dan dengan sembilan indikator pengukuran yang merupakan kombinasi dari Bangun (2012), Wibowo (2013) dan Angela (2014). Teknik analisis data yang digunakan pada penelitian ini adalah uji interaksi atau Moderated Regression Analysis (MRA). 


\section{HASIL DAN PEMBAHASAN}

PT SM Tbk merupakan perusahan yang bergerak di bidang industri jamu. Perusahaan ini merupakan perusahaan operasional penghasil jamu terbesar di Indonesia. Dalam penelitian ini peneliti meneliti di PT SM di Karangjati, Kab. Semarang khususnya di bagian gudang. Gudang merupakan tempat pertama kali bahan baku masuk dan awal proses bahan baku. Melihat hal tersebut tentunya diperlukan kinerja karyawan yang tinggi.

Dalam penelitian ini terdapat 93 responden yang bekerja di PT SM Karangjati Semarang, sebagai karakteristik responden dijabarkan menjadi lima antara lain jenis kelamin, usia, posisi atau jabatan, departemen, dan lama bekerja. 93 responden karyawan pria atau laki laki lebih mendominasi sebesar 59,1 persen dibanding wanita. Untuk rentang usia kebanyakan yang bekerja di usia antara 26 - 40 Tahun sebesar 69,9 persen. Sedangkan untuk posisi atau jabatan didominasi oleh karyawan operator sebesar 83,9 persen. Untuk dibagian gudang sendiri dibagi menjadi 2 bagian gudang yaitu GBBNS (Gudang Bahan Baku Non Simplisia) dan GBBS (Gudang Bahan Baku Simplisia), dimana rata rata yang banyak karyawannya di bagian GBBNS (Gudang Bahan Baku Non Simplisia) sebesar 75,3 persen. Dikarenakan GBBNS lebih besar dan karyawannya lebih banyak dibanding GBBS. Untuk karyawan yang lama bekerja kebanyakan $>10$ Tahun sebesar 35,5 persen yang bekerja di PT SM.

\section{Hasil Penelitian}

Budaya Kaizen merupakan budaya yang berasal dari Jepang. Kaizen merupakan istilah dari Jepang yang berarti perbaikan berkesinambungan. Budaya Kaizen merupakan budaya perbaikan yang melibatkan semua orang, baik manajer maupun karyawan dan melibatkan biaya dalam jumlah tak seberapa atau dengan biaya rendah (Imai, 1998:1).
Tabel 1. Nilai Rata-rata Budaya Kaizen

\begin{tabular}{|c|c|c|c|}
\hline No & Pertanyaan & Mean & Kategori \\
\hline 1 & $\begin{array}{l}\text { Rata-rata Ringkas } \\
\text { (Seiri) }\end{array}$ & 4,20 & Sangat Tinggi \\
\hline 2 & $\begin{array}{l}\text { Rata-rata Rapi } \\
\text { (Seiton) }\end{array}$ & 4,26 & Sangat Tinggi \\
\hline 3 & $\begin{array}{l}\text { Rata-Rata Resik } \\
\text { (Seiso) }\end{array}$ & 4,29 & Sangat Tinggi \\
\hline 4 & $\begin{array}{l}\text { Rata-Rata Rawat } \\
\text { (Seiketsu) }\end{array}$ & 4,15 & Tinggi \\
\hline 5 & $\begin{array}{l}\text { Rata-Rata Raji } \\
\text { (Shitsuke) }\end{array}$ & 3,99 & Tinggi \\
\hline & $\begin{array}{l}\text { Rata-Rata Budaya } \\
\text { Kaizen }\end{array}$ & 4,18 & Tinggi \\
\hline
\end{tabular}

Sumber: Data Olahan Ms. Excel, 2018

Pada tabel 1, budaya kaizen menunjukkan nilai rata-rata tertinggi dari variabel budaya kaizen adalah "Saya membersihkan area kerja setelah selesai melakukan pekerjaan" dengan rata-rata jawaban dari 93 responden sebesar 4,38. Dengan angka tersebut menunjukkan bahwa karyawan digudang sendiri selalu menjaga kebersihan area kerja dimana tujuan dari membersihkan area kerja setelah melakukan pekerjaan yaitu agar area menjadi bersih dan nyaman untuk bekerja yang dapat meningkatkan kinerja dari karyawan itu sendiri . Nilai rata-rata dari 15 pertanyaan di variabel budaya kaizen tersebut sebesar 4,18 yang berarti budaya kaizen termasuk dalam kategori tinggi. Dari ke 15 pertanyaan di variabel budaya kaizen ada tujuh pertanyaan yang termasuk kategori sangat tinggi. Hal tersebut menunjukkan bahwa budaya kaizen sangat lah penting dalam pekerjaan dimana dengan budaya tersebut walaupun sepele dapat membawa dampak besar dikemudian hari.

Reward memiliki peran penting dalam meningkatkan kinerja karyawan. Menurut Noe, dkk (2011:101) menyatakan bahwa kinerja yang tinggi yang diikuti reward akan menyebabkan kinerja yang tinggi juga dan cenderung akan terjadi di masa mendatang. 
Tabel 2. Nilai Rata-rata Reward

\begin{tabular}{clcc}
\hline No & \multicolumn{1}{c}{ Pertanyaan } & Mean & Kategori \\
\hline 1 & Rata-Rata Non Finansial & 3,54 & Tinggi \\
2 & Rata-Rata Finansial & 2,97 & Sedang \\
\hline & Rata-Rata Reward & 3,28 & Sedang
\end{tabular}

Sumber: Data Olahan Ms. Excel, 2018

Pada tabel 2, reward ini menunjukkan nilai rata rata tertinggi dari variabel reward dengan pertanyaan "Atasan bagian tempat saya bekerja memberikan dukungan kepada karyawan untuk menerapkan budaya kaizen (5R) dengan baik" dengan rata rata jawaban dari 93 responden sebesar 3,92. Ini menunjukkan bahwa reward non finansial memiliki pengaruh kepada karyawan dimana dukungan dari atasan sangatlah berarti bagi karyawan. Karyawan merasa dihargai dan dekat dengan atasan tanpa ada jarak ataupun status jabatan. Hal ini juga dapat berdampak pada kinerja karyawan yang semakin tinggi karena atasan mendukung apa yang dilakukan oleh karyawan mengenai budaya kaizen atau 5R. Untuk nilai rata-rata dari 13 indikator pertanyaan di variabel reward (X2) sebesar 3,28 yang berarti variabel kinerja masuk dalam kategori sedang.

Kinerja merupakan suatu hasil kerja yang telah dicapai oleh karyawan dalam kurun waktu tertentu (Wirawan, 2009).

Tabel 3. Nilai rata-rata Kinerja

\begin{tabular}{clcc}
\hline No & \multicolumn{1}{c}{ Pertanyaan } & Mean & Kategori \\
\hline 1 & Rata-Rata Hasil Kerja & 4,00 & Tinggi \\
2 & Rata-Rata Perilaku Kerja & 4,02 & Tinggi \\
3 & Rata-Rata Sifat Pribadi & 3,88 & Tinggi \\
\hline & Rata-Rata Kinerja & 3,97 & Tinggi
\end{tabular}

Sumber: Data Olahan Ms. Excel, 2018

Tabel di atas menunjukkan nilai rata rata tertinggi pada variabel kinerja dengan pertanyaan "Saya teliti dalam menyelesaikan suatu pekerjaan" dengan rata-rata jawaban dari 93 responden sebesar 4,05. Hal tersebut menunjukkan bahwa karyawan di PT. SM khususnya dibagian gudang teliti dalam menyelesaikan pekerjaan. Untuk nilai ratarata dari 9 indikator pertanyaan di variabel kinerja karyawan (Y) sebesar 3,97 yang berarti variabel kinerja masuk dalam kategori tinggi. Rata-rata jawaban pada kuesioner menunjukkan dalam kategori tinggi, ini berarti bahwa karyawan dibagian gudang memiliki kinerja yang tinggi. Dengan adanya kinerja yang tinggi diharapkan proses selanjutnya akan berjalan menjadi lebih baik.

Dalam penelitian ini menggunakan uji analisis regresi linier sederhana. Fungsi dilakukannya uji analisis regresi linier sederhana adalah untuk melihat pengaruh budaya kaizen terhadap kinerja karyawan yang merupakan hipotesis pertama dalam penelitian. Berdasarkan analisis regresi linier berganda, diperoleh persamaan regresi linier sederhana antara variabel budaya kaizen (X1) dan Kinerja (Y) sebagai berikut:

$$
\mathrm{Y}=1,091+0,688 \mathrm{X} \text {. }
$$

Dari persamaan regresi linier sederhana tersebut dapat dilihat bahwa nilai koefisien dari variabel budaya kaizen adalah positif. Maka dapat disimpulkan bahwa budaya kaizen memiliki pengaruh yang positif terhadap kinerja karyawan. Jadi jika karyawan melakukan budaya kaizen dengan disiplin maka semakin tinggi kinerja dari karyawan tersebut. Jika nilai signifikansi variabel lebih kecil dari 0,05 maka variabel tersebut memiliki pengaruh. Dilihat dari nilai signifikansi dari variabel budaya kaizen menunjukkan bahwa nilai signifikansinya sebesar $0,000<0,05$ yang berarti variabel budaya kaizen memiliki pengeruh terhadap kinerja karyawan.

Nilai koefisien determinasi sebesar 0,554. Hal tersebut menunjukkan bahwa presentase dari pengaruh variabel budaya kaizen terhadap kinerja karyawan sebesar $55,4 \%$, untuk sisanya dipengaruhi oleh variabel-variabel lain yang tidak dimasukkan dalam model penelitian ini.

Setelah dilakukannya uji regresi linier sederhana maka langkah selanjutnya yang dilakukan uji MRA atau analisis regresi moderasi. Dilakukannya uji analisis regresi moderasi atau MRA untuk menguji hipotesis yang kedua yaitu melihat bagaimana pengaruh budaya kaizen terhadap kinerja karyawan 
dengan dimoderasi oleh reward. Persamaan regresi moderasi adalah sebagai berikut:

$$
\mathrm{Y}=-3,011+1,555 \mathrm{X}_{*}+1,360 \mathrm{X}_{2}-0,289
$$

Nilai signifikansi dari hasil interaksi antara budaya kaizen dan reward sebesar 0,023 $<0,05$. Jika nilai signifikansi dari variabel moderasi lebih kecil dari 0,05 maka dapat dikatakan variabel tersebut dapat memoderasi dari pengaruh variabel independen dan variabel dependen. Jadi dapat disimpulkan bahwa reward merupakan variabel yang dapat memoderasi interaksi antara budaya kaizen dan kinerja karyawan.

Nilai koefisien determinasi sebesar 0,596 atau $59,6 \%$. Nilai koefisien determinasi berbeda dengan sebelumnya. Dimana nilai koefisien determinasi yang sebelumnya sebesar 55,4\%. Nilai koefisien determinasi setelah ada variabel moderasi menjadi lebih besar. Sehingga dapat disimpulkan bahwa reward merupakan variabel moderasi yang dapat memperkuat pengaruh antara budaya kaizen dengan kinerja karyawan.

\section{Pembahasan}

Pada variabel budaya kaizen, menunjukkan hasil bahwa budaya kaizen di PT SM khususnya dibagian gudang termasuk pada kategori tinggi. Budaya kaizen di PT SM sendiri merupakan hal yang wajib bagi karyawan yang bekerja di sana. Menurut Manajer R \& D di PT SM, budaya kaizen merupakan hal yang wajib yang harus dilakukan oleh karyawan di PT SM sendiri. Dimana dampak dari budaya kaizen akan meningkatkan kinerja karyawan menjadi lebih baik dibanding sebelumnya. Sejak adanya budaya kaizen juga di area kerja tampak bersih, peralatan tertata dengan rapi dan ditata sesuai tempat dan fungsinya dan lain sebagainya. Hal tersebut dapat membuat karyawan nyaman dalam bekerja dan dapat meningkatkan kinerja karyawan. Di gudang sendiri merupakan tempat pertama kali bahan baku masuk, pertama kali bahan baku diproses dan dalam pemrosesan harus steril. Budaya kaizen ini sendiri memiliki peran penting di gudang yang mana jika awal proses dilakukan dengan baik maka proses selanjutnya akan menjadi baik juga.

Untuk variabel reward menunjukkan hasil bahwa nilai rata-ratanya masuk dalam kategori sedang. Di PT SM Karangjati Semarang ada lomba mengenai budaya kaizen, dimana lomba ini dilaksanakan setiap enam bulan sekali dan dilombakan dengan departemen lain. Jika departemen melakukan dengan baik dibanding departemen lain maka departemen yang melakukan budaya kaizen dengan maksimal akan mendapatkan reward. Reward sendiri dibagi menjadi dua yaitu reward non finacial dan reward financial. Untuk reward non financial sendiri yaitu diberikan pataka atau bendera biru untuk menandakan bahwa departemen yang telah mendapatkan bendera biru itu melakukan budaya kaizen dengan maksimal. Dan sebaliknyajika ada departemen yang tidak melakukan dengan baik atau belum maksimal maka akan diberikan pataka atau bendera kuning fungsinya untuk menandakan bahwa departemen tersebut belum melakukan dengan baik atau belum maksimal dalam melakukan budaya kaizen. Untuk pataka atau bendera tersebut hanya ada dua, jadi untuk satu untuk yang terbaik dalam melakukan budaya kaizen dan yang satunya untuk yang belum melakukan budaya kaizen dengan baik atau belum maksimal. Dukungan dari atasan juga terus dilakukan agar karyawannya lebih giat dalam menerapkan budaya kaizen di area kerja. Untuk reward financial departemen yang melakukan budaya kaizen dengan maksimal maka akan diberikan uang, tetapi untuk nominalnya besarannya dirahasiakan oleh perusahaan.

Pada hasil mengenai variabel kinerja karyawan menunjukkan hasil bahwa nilai rata-ratanya masuk dalam kategori tinggi. Hal tersebut menunjukkan bahwa karyawan di gudang PT SM Karangjati Semarang memiliki kinerja yang tinggi dan tidak menutup kemungkinan di departemen lain memiliki kinerja yang tinggi juga. Di bagian gudang bahan baku ini merupakan departemen dimana bahan baku masuk dan awal diproses. 
Tentunya dengan adanya ketelitian dalam menyelesaikan pekerjaan dapat membuat proses selanjutnya menjadi baik dalam artian kinerja pada bagian awal benar-benar diperhatikan dan harus teliti karena akan berdampak pada proses selanjutnya. Maka bisa disimpulkan jika kinerja karyawannya di bagian gudang tinggi maka untuk menuju proses setelah bahan baku diolah di gudang menghasilkan olahan yang baik dalam artian untuk kemungkinan barang not good itu kecil. Perusahaan juga memperhatikan mengenai kinerja karyawannya. Dengan adanya kinerja karyawan yang tinggi maka tujuan dari perusahaan juga dapat tercapai. Kemungkinan juga perusahaan untuk maju dan berkembang juga lebih cepat dikarenakan adanya kinerja yang tinggi dari karyawan di perusahaannya.

Dalam penelitian ini memiliki dua hipotesis. Hasil penelitian ini menunjukkan bahwa hipotesis yang pertama diterima yaitu ada pengaruh budaya kaizen terhadap kinerja karyawan. Hal tersebut terbukti dari hasil pengujian analisis regresi linier sederhana yang menunjukkan bahwa budaya kaizen berpengaruh positifterhadap kinerjakaryawan. Hasil dalam penelitian ini juga mendukung dari hasil penelitian yang dilakukan oleh Rohman (2016), Mulyawati (2015) dan Hakim, dkk (2016) yang menyebutkan bahwa budaya kaizen memiliki pengaruh positif terhadap kinerja karyawan. Maka dapat disimpulkan bahwa budaya kaizen mempunyai pengaruh dalam menyebabkan kinerja karyawannya menjadi kinerjanya tinggi.

Pada penelitian-penelitian terdahulu yang dilakukan oleh Demokrat (2011) dan Nathania (2016) mengenai kompensasi atau reward bahwa penelitian sebelumnya menguji pengaruh. Dalam penelitian ini menambahkan dari penelitian sebelumnya bahwa bukan hanya berpengaruh tetapi lebih kepada memoderasi pengaruh dari kedua variabel antara budaya kaizen dan kinerja karyawan. Hasil penelitian ini juga menunjukkan bahwa hipotesis yang kedua juga diterima, dimana budaya kaizen memiliki pengaruh terhadap kinerja karyawan yang dimoderasi oleh reward. Maka dalam hasil penelitian ini sekaligus dapat menunjukkan bahwa reward bisa menjadi variabel moderasi dalam menjelaskan pengaruh budaya kaizen terhadap kinerja karyawan. Maka dapat disimpulkan bahwa variabel reward dapat menjadi variabel moderasi yang dapat memperkuat pengaruh antara budaya kaizen dan kinerja karyawan. Ada penelitian yang lain, untuk reward menjadi variabel moderasi yang dilakukan oleh Angela (2014) mengenai pengaruh implementasi total quality management terhadap kinerja bank umum dengan budaya organisasi dan sistem penghargaan sebagai variabel moderasi dan Putro (2010) mengenai pengaruh total quality management terhadap kinerja manajerial dengan sistem penghargaan sebagai variabel moderasi. Dari kedua penelitian tersebut menunjukkan hasil bahwa sistem penghargaan atau reward dapat memperkuat pengaruh dari kedua variabel dalam penelitian tersebut.

Perusahaan membuat perlombaan dalam melakukan budaya kaizen di area kerja setiap departemen yang dilakukan setiap enam bulan sekali. Dimana perusahaan memberikan reward kepada departemen yang melakukan budaya kaizen dengan maksimal. Reward yang diberikan ada dua yaitu pataka atau bendera berwarna biru dan uang. Untuk uang sendiri tidak disebutkan nominalnya karena itu rahasia dari perusahaan. Fungsi diberikan pataka atau bendera berwarna biru ini menandakan bahwa departemen melakukan budaya kaizen dengan maksimal tanpa ditemukan temuan. Tujuan diberikan reward untuk meningkatkan kinerja karyawannya agar kinerja karyawan semakin meningkat. Ada juga punishment bagi departemen yang tidak melakukan budaya kaizen dengan baik dalam artian departemen tersebut mendapat temuan oleh pihak audit sebagai contoh ditemukan area kerjanya kotor, peralatan tidak sesuai pada tempatnya dan lain sebagainya. Untuk departemen yang tidak melakukan budaya kaizen dengan baik akan diberikan pataka atau bendera kuning di departemennya. Fungsi dari diberikannya pataka atau bendera kuning untuk menandakan bahwa depertemen tersebut tidak melakukan 
budaya kaizen dengan baik dan dapat dijadikan motivasi juga agar lebih maksimal dalam melakukan budaya kaizen. Dalam artian jika departemen yang mendapatkan pataka atau bendera kuning maka departemen tersebut akan merasa malu dan kedepannya akan memperbaiki dan melakukan budaya kaizen dengan baik. Harapan dilakukannya lomba dalam melakukan budaya kaizen agar kinerja karyawan dapat meningkat atau dalam kategori kinerja karyawannya tinggi. Dan tidak hanya itu saja, agar perusahaan mampu bersaing dengan perusahaan-perusahaan lain, lebih maju dan lebih berkembang di kemudian hari.

\section{PENUTUP}

Penelitian ini bertujuan untuk menganalisis pengaruh budaya kaizen terhadap kinerja karyawan dan pengaruh budaya kaizen terhadap kinerja karyawan dengan reward sebagai variabel moderasi. Dengan dilakukannya budaya kaizen ini harapan dapat memajukan perusahaan secara berangsur dalam memberikan hasil untuk jangka panjang. Berdasarkan dari hasil analisis yang telah dilakukan, maka dapat disimpulkan bahwa dari hipotesis yang pertama menunjukkan budaya kaizen berpengaruh poterhadap kinerja karyawan. Dalam artian semakin tinggi tingkat budaya kaizen maka kinerja dari karyawan akan semakin besar atau tinggi. Hasil analisis dalam penelitian ini menunjukkan bahwa sumbangan pengaruh dari variabel budaya kaizen terhadap kinerja karyawan adalah sebesar 55,4\% sedangkan 54,6\% dipengaruhi oleh variabel lain.

Untuk hipotesis yang kedua, budaya kaizen berpengaruh terhadap kinerja karyawan yang dimoderasi oleh reward. Hasil analisis dalam penelitian ini menunjukkan bahwa reward bisa menjadi variabel yang memoderasi dari pengaruh budaya kaizen terhadap kinerja karyawan. Variabel reward memperkuat pengaruh antara budaya kaizen dan kinerja karyawan. Reward disini sebagai penyemangat atau motivasi agar karyawan mau melakukan budaya kaizen dengan baik dan dampaknya kinerja karyawan juga akan meningkat. Jika dilihat dari hasil penelitian mengenai reward yang memoderasi dari pengaruh budaya kaizen terhadap kinerja karyawan bahwa sumbangan dari reward sebagai variabel moderasi 4,2\%. Jadi dari awalnya sebelum adanya moderasi hanya menyumbangkan pengaruh budaya kaizen terhadap kinerja karyawan sebesar 55,4\% dan menjadi $59,6 \%$ setelah adanya reward yang memoderasi antara pengaruh budaya kaizen terhadap kinerja karyawan. Walaupun hanya berubah sedikit tetapi setidaknya terlihat trend positif meningkat dan berbeda sebelum kedua variabel tersebut dimoderasi.

Pada variabel budaya kaizen ada dua pernyataan dengan rata-rata terendah dibanding pernyataan yang lain yaitu yang pertama mengenai mengecek kebersihan area kerja sebelum bekerja. Kebersihan area kerja merupakan hal terpenting dan sangatlah berpengaruh pada kenyamanan karyawan saat bekerja apalagi jika area kerjanya kotor akan sangat mengganggu saat bekerja. Untuk itu alangkah baiknya membersihkan area kerja setelah bekerja, jadi untuk keesokan harinya langsung bisa bekerja dengan nyaman dan tidak membersihkan area kerja lagi. Pernyataan yang kedua yaitu disiplin terhadap norma kerja. Disiplin merupakan hal terpenting dalam bekerja apalagi harus taat kepada norma kerja. Sebaiknya mengikuti norma kerja yang ada seperti contoh saat istirahat tepat waktu dan tidak molor melebihi jam yang sudah ditentukan, kemudian saat jam pulang kerja harus tepat waktu, tidak mendahuli sebelum jam kerja pulang.

Pada variabel reward ada dua pernyataan dengan rata rata terendah dibandingkan dengan pernyataan yang lain yaitu mengenai bonus yang didapat apakah telah sesuai yang diharapkan dan bonus dari penerapan budaya kaizen. Sebaiknya perusahaan memberikan sosialisasi mengenai reward yang diterima dengan jumlah tertentu dari awal, dari hal tersebut karyawan semakin terpacu dan akan berlomba lomba dalam melakukan budaya 
kaizen dengan maksimal di setiap departemen di perusahaan.

Dalam penelitian ini budaya kaizen memiliki pengaruh positif terhadap kinerja karyawan. Hal tersebut mendukung dari penelitian-penelitian yang dilakukan oleh Rohman (2016), Mulyawati (2015) dan Hakim, dkk (2016) yang menyebutkan bahwa budaya kaizen memiliki pengaruh positif terhadap kinerja karyawan. Jika budaya kaizen dilakukan dengan maksimal atau dengan teratur maka akan berdampak pada kinerja karyawan yang semakin meningkat atau tinggi. Untuk reward ternyata setelah diuji dapat memoderasi antara pengaruh budaya kaizen terhadap kinerja karyawan. Penelitian ini menambahkan dari penelitian-penelitian yang dilakukan oleh Demokrat (2011) dan Nathania (2016) mengenai kompenasi atau reward bahwa penelitian sebelumnya menguji pengaruh. Tetapi dalam penelitian ini lebih kepada memoderasi pengaruh dari kedua variabel antara budaya kaizen dan kinerja karyawan. Jadi dapat disimpulkan bahwa reward dapat memperkuat dari pengaruh antara budaya kaizen terhadap kinerja karyawan.

Keterbatasan dari penelitian ini adalah dalam pengukuran reward yang dibagi menjadi dua, reward non financial dan reward financial. Tetapi peneliti tidak dapat menggali lebih dalam antara reward non financial dan reward financial yang mana yang lebih berdampak, atau bagaimana proses reward itu berdampak atau lebih memperkuat. Peneliti tidak mendapatkan hal tersebut dikarenakan pertanyaan peneliti termasuk kategori pertanyaan tertutup. Penelitian ini hanya dapat melihat tingi atau rendah untuk elemenelemen tertentu dan bisa dikatakan tidak bisa langsung menunjukkan masalah yang terjadi. Peneliti hanya dapat memetakkan tetapi tidak spesifik. Maka saran untuk penelitian selanjutnya disarankan untuk menggunakan metode kualitatif, supaya bisa memahami reward seperti apakah yang memperkuat atau memperlemah pengaruh dari budaya kaizen terhadap kinerja karyawan. Penelitian ini sudah membuktikan bahwa reward dapat memoderasi pengaruh budaya kaizen terhadap kinerja karyawan.

\section{DAFTAR PUSTAKA}

Angela, A. 2014. Pengaruh Implementasi Total Quality Management terhadap Kinerja Bank Umum dengan Budaya Organisasi dan Sistem Penghargaan sebagai Variabel Moderasi. Jurnal Akuntansi, Vol.6 No.2 November 2014: 42-58.

Bangun, W. 2012. Manajemen Sumber Daya Manusia. Jakarta: Erlangga.

\section{Creswell, J. W. 2010. Research Design Pendekatan Kualitatif, Kuantitatif dan Mixed.} Yogyakarta: Pustaka Pelajar.

Demokrat, S. N. 2011. Pengaruh Kompensasi terhadap Kinerja Dengan Motivasi Kerja sebagai Variabel Moderating, Studi pada Kantor Pelayanan Perbendaharaan Negara Se-Jawa Tengah dan Daerah Istimewa Yogyakarta. http://eprints.uns.ac. id/10413/1/186401111201111531.pdf. (Diakses 10 Juni 2017).

Dessler, G. 2009. Manajemen Sumber Daya Manusia. Jilid 1 Edisi Kesembilan. Jakarta: PT Indeks.

Devi, E. K. 2009. Analisis Pengaruh Kepuasan Kerja dan Motivasi terhadap Kinerja Karyawan dengan Komitmen Organisasional sebagai Variabel Intervening (studi pada karyawan outsourcing PT Sumeru Karya Buana Semarang). http://eprints.undip.ac.id/17249/1Eva Kris_Diana_Devi.pdf. (Diakses 16 Juli 2017). 
Fajarrini P. Hakam Danti, M. S. 2014. Pengaruh Kompenasi terhadap Semangat Kerja Karyawan (Studi pada Karyawan CV. Sejahtera, Pakisaji, Malang). Jurnal Administrasi Bisnis (JAB), Vol. 9 No. 2 April 2014.

Imai, M. 1998. Gemba Kaizen: Pendekatan Akal Sehat, Berbiaya Rendah Pada Manajemen. Jakarta: Pustaka Binaman Pressindo.

Kadarisman, M. 2012. Manajemen Kompensasi. Jakarta: Raja Grafindo Persada.

Kuncoro, P. M. 2011. Metode Kuantitatif, Teori dan Aplikasi untuk Bisnis dan Ekonomi. Yogyakarta: UUP STIM YKPN.

Liana, L. 2009. Penggunaan MRA dengan SPSS untuk menguji Pengaruh Variabel Moderating terhadap hubungan antara Variabel Independen dan Variabel Dependen. Jurnal Teknologi Informasi DINAMIK, volume XIV, No.2, Juli 2009: 90-97.

Mariam, R. 2009. Pengaruh Gaya Kepemimpinan dan Budaya Organisasi terhadap Kinerja Karyawan melalui Kepuasan Kerja Karyawan sebagai Variabel Intervening (Studi pada Kantor Pusat PT. Asuransi Jasa Indonesia). http://eprints.undip.ac.id/18830/1/RANI MARIAM.pdf. (Diakses 1 Juli 2017).

Melindasari, I. 2015. Pengaruh Lingkungan Kerja dan Stres Kerja terhadap Kinerja Karyawan P. Federal International Finance (FIF) Gresik. http://ibrary.uwp.ac.id/digilib/files/ disk1/11/--iinmelinda-508-1-01100000-4.pdf. (Diakses 18 Juni 2017).

Mohamamad Ariful Hakim, M. A. 2016. Pengaruh Budaya Kaizen terhadap Motivasi dan Kinerja,Studi pada Karyawan PT Semen Indonesia Tbk. Jurnal Administrasi Bisnis (JAB), Vol. 35 No. 1 Juni 2016.

Moorhead, G. 2013. Perilaku Organisasi: Manajemen Sumber Daya Manusia dan Organisasi. Jakarta: Salemba Empat.

Mulyawati, F. 2015. Pengaruh Budaya Kaizen terhadap Kinerja Karyawan PT. Gistex Garmen Indonesia. http://repository.widyatama.ac.id/xmlui/handle/123456789/6287. (Diakses 1Juli 2017).

Nathania, C. 2016. Pengaruh Kompensasi terhadap Kinerja Karyawan pada PD Damai Motor Bandar Lampung. http://digilib.unila.ac.id/21500/20/SKRIPSI\%20TANPA\%20 BAB\%20PEMBAHASAN.pdf. (Diakses 1 Juli 2017).

Noe, R. A. 2011. Manajemen Sumber Daya Manusia: Mencapai Keunggulan Bersaing. Jakarta: Salemba Empat.

Putro, S. E. 2010. Pengaruh Total Quality Management terhadap Kinerja Manajerial dengan Sistem Penghargaan (reward) sebagai Variabel Moderasi. Jurnal Media Mahardika, Vol. 8 No.3 Mei 2010.

Rahmalia Sari, M. M. 2012. Pengaruh Kepemimpinan, Motivasi, dan Stres Kerja terhadap Kinerja Karyawan pada Bank Syariah Mandiri Kantor Cabang Makasar. Jurnal Analisis, Juni 2012, Vol.1 No.1 : 87 - 93 .

Reza, R. A. 2010. Pengaruh Gaya Kepemimpinan, Motivasi dan Disiplin Kerja terhadap Kinerja Karyawan PT Sinar Santosa Perkasa Banjarnegara. http://eprints.undip.ac.id/24466/1/ skripsi-REGINA_ADITYA_REZA.pdf. (Diakses 22 Juli 2017)

Rohman, M. 2016. Pengaruh Budaya Kaizen terhadap Kinerja Karyawan MPM Insurance Palembang. $\quad$ http://repo.iba.ac.id/index.php?p=fstream-pdf\&fid=417\&bid=954Skripsi. 
(Diakses 1 Juli 2017).

Ruslianto. 2013. Penerapan Seiri, Seiton, Seiso, Seiketsu, dan Shitsuke(5S)di WorkshopPT. Hino Motors Sales Indonesia. http://eprints.uny.ac.id/20184/1/RUSLIANTO 09504241024. pdf. (Diakses 22 Juli 2017).

Sari, E. V. 2013. Pengaruh Budaya Organisasi terhadap Kinerja Karyawan pada PT Taspen (Persero) Cabang Yogyakarta. http://eprints.uny.ac.id/16120/1/TA\%20complete.pdf. (Diakses 10 Juni 2017).

Sinaga, M. 2008. Analisis Pengaruh Budaya Organisasi dan Reward terhadap Kinerja karyawan pada PT. Soelong Laoet Medan. http://s3.amazonaws.com/academia.edu. documents/39128331/ANALISIS_PENGARUH_BUDAYA_ORGANISASI_DAN REWARD TERHADAP KINERJA KARYAWAN_PADA_PT. SOELONG LAOET MEDAN.pdf?AWSAccessKeyId=AKIAIWOWYYGZ2Y53UL3A\&Exp

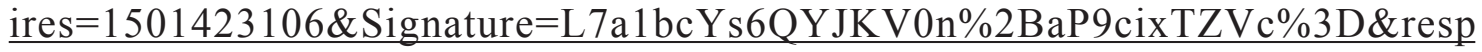
onse-contentdisposition $=$ inline $\% 3 \mathrm{~B} \% 20$ filename $\% 3$ DANALISIS PENGARUH BUDAYA O RGANISASI DAN.pdf. (Diakses 10 Juni 2017)

Sinambela, P. D. 2012. Kinerja Pegawai: Teori Pengukuran dan Implikasi. Yogyakarta: Graha Ilmu.

Suryoadi, Y. 2012. Pengaruh Pelatihan dan Kepuasan Kompensasi terhadap Kinerja Karyawan pada PT Bank Muamalat Indonesia Cabang Semarang. http://eprints.undip.ac.id/35556/1/ Skripsi_SURYO ADI.pdf. (Diakses 1 Juli 2017).

Tangguh, E. N. 2015. Peran Semangat Kerja sebagai Mediasi pengaruh Budaya 5S (Seiri, Seiton, Seiso, Seiketsi, dan Shitsuke) Keselamatan dan Kesehatan Kerja (K3) terhadap Produktivitas Kerja pada PT. Sariguna Prima Tirta cabang Jember. http://repository.unej. ac.id/bitstream/handle/123456789/66793/EDWIN\%20NOVIANTO\%20T.,S.Si\%20 -\%20130820101053.pdf? sequence=1Tesis. (Diakses 22 Juli 2017).

Tarigan, A. F. 2011. Analisis Faktor-Faktor yang mempengaruhi Kinerja Pegawai dalam Organisasi Sektor Publik. http://eprints.undip.ac.id/29361/1/Skripsi003.pdf. (Diakses 18 Juni 2017).

Wibowo, P. D. 2013. Manajemen Kinerja. edisi ketiga. Jakarta: Rajawali Pers.

Wirawan. 2009. Evaluasi Kinerja Sumber Daya Manusia: Teori Aplikasi dan Penelitian. Jakarta: Salemba Empat.

Yusuf, P. D. 2014. Metode Penelitian: Kuantitatif, Kualitatif, dan Penelitian Gabungan. Jakarta: Kencana.

Zamzami.2016. Faktor-faktoryang MempengaruhiKinerja Karyawan Ditinjau dalam Pandangan Syari'ah di Restoran Abdullah HAR Cabang Palembang. INTELEKTUALITA, 5(1), 67-80. 